
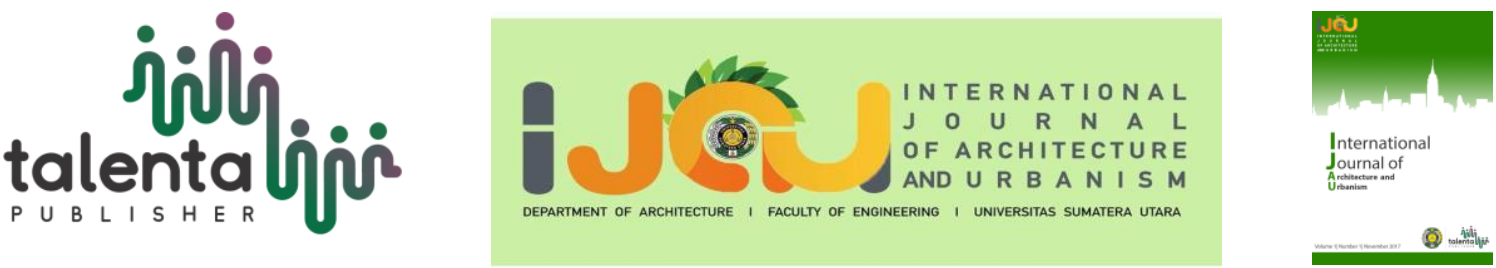

\title{
Characterizing the Cultural Spatial Structure of The Pangururan District Context
}

\author{
Hery Samuel Simarmata ${ }^{1^{*}}$ \\ ${ }^{I}$ Independent Researcher, Medan, Indonesia
}

\begin{abstract}
An area is basically formed due to geographical conditions and local cultural aspects that influence it. In this Pangururan village, its geographical condition is close to Lake Toba, and the Toba Batak culture is the most abundant culture in this region. The Toba Batak culture generally inhabits around of Lake Toba in North Sumatra, which means it is located between a lake and a mountain so that the average community works as fishermen and farmers. This led to the growth of settlements around the hill area and also on the edge around Lake Toba. This is certainly an aspect that affects the characterizing of the cultural spatial structure of Pangururan district context. The purpose of this study was to get an overview of the Cultural Spatial Structure of Pangururan Regency.
\end{abstract}

Keyword: culture, Pangururan, Lake Toba

Received 19 September 2021 | Revised 24 October 2021 | Accepted 25 October 2021

\section{Introduction}

Pangururan District is located in Samosir Regency, North Sumatra where there are about 28 villages with a total population of around 30,000 people [1]. This district is located next to Lake Toba, which is Pangururan District, which is an area that has a high enough potential in managing development in accordance with lakeside tourism and community culture. Pangururan is an area that has an original cultural style that can be seen from the structure of the village space. Ecological discussion on the process of the existence of villages in Pangururan becomes important to study because of the interrelationship of rituals and ideologies that interact with the environment.

The Batak Toba culture is the most abundant culture in this area. The Toba Batak culture generally inhabits around of Lake Toba in North Sumatra, which means it is located between a lake and a mountain so that the average community works as fishermen and farmers. This led to the growth of settlements around the hill area and also on the edge around Lake Toba.

\footnotetext{
${ }^{*}$ Corresponding author at: Karya Wisata Komp. Citra Wisata Blok XIV No. 17, Medan, Indonesia

E-mail address: simarmatarsitektur@gmail.com
} 
Based on an ecological point of view, in forming a village in Pangururan District, the concept of the environment cannot be separated, which involves an active role in human activities. and culture that cannot be separated from others.

This discussion about characterizing the spatial culture of the Pangururan district context is important to study to find out that there is a link between the ecological aspects of the area located around Lake Toba and also the cultural aspects of the Toba Batak which are the culture of the people who most influence this area.

\section{Literature Review}

\section{Spatial Structure}

The spatial aspect is an element in the spatial arrangement, because space is a surface aspect, while spatial includes the structure in it, and reflects the characteristics of space [2]. The spatial structure of traditional settlements can be categorized into two basic relationships, the first is global space with space elements and the second is the relationship between the elements of space itself. There are two basic relationships manifested in 4 (four) concepts of spatial structure, namely placement and sequence as the relationship between global space and element space, while interaction and hierarchy as the relationship between element space. Global space is based on the cognition of villagers, while land, roads, housing units, environmental facilities are element spaces [3].

The direction of settlement growth will produce new patterns according to its layout. So that the settlement layout pattern can basically be categorized into four divisions, namely: (1) Boundaries are the territory of a settlement area determined by the local community for generations, (2) Types of facilities (mass) by grouping physical elements for activities and socializing as well as facilities that support people's lives, (3) Spatial planning (zone), dividing the function of spatial planning with the structure of the community's area in carrying out activities and activities, such as spatial planning based on beliefs, norms, customs and community habits, (4) Decorative variety, in the form of natural or artificial factors that are commonly found in settlements. This can also be motivated by the culture and beliefs of the local community [4].

\section{Culture}

Culture as 'systems of socially transmitted behaviour patterns that serve to relate human communities to their ecological settings. Habitation is caused by human behavior that has patterns of behavior, power, and activities that connect humans with their environment to manage and transform nature into a living environment [5]. 
Culture is human effort in producing a work in maintaining offspring and seeking resources in nature and its surroundings to remain prosperous. In the process, culture emerges as a form of human response in facing obstacles and in the process of adapting to its environment, both as cultural and biological beings [6]. Culture is a complex includes knowledge, belief, art, morals, customs and abilities and other habits that humans have as part of society [7].

Compared to social identity, this cultural identity is related to a sense of solidarity towards the ideals of the cultural group concerned, and the result is an attitude, beliefs, and behavior of a person towards himself and others. Social structure affects the special character of dwellings, settlements and villages. Likewise, the ritual traditions of a society affect the spatial organization of a village, while marriage traditions, and other traditions, affect the layout and development of a community's village. Specific characteristics of the socio-cultural community will produce vernacular architecture both in buildings, settlements and villages

\section{Methodology}

The research was carried out using qualitative methods, through the collection of literature studies and through information on the internet relating to research discussions. Regarding characterizing the cultural spatial structure, the main factor is the influence of environment and culture in the pattern of spatial growth in Pangururan District.

The location chosen is Pangururan District and the object under study is the Cultural Spatial Structure which is formed by the ecological and cultural factors of the people in this sub-district.

\section{$4 \quad$ Result and Discussion}

The waterfront environment can affect community settlement patterns. This happens because the formation of a settlement pattern is based on several aspects such as ideology, culture and the physical form of nature [8]. In hilly areas, settlement patterns generally follow the contours of the land, which are relatively flat and tend to have relatively regular patterns, such as grid and linear patterns. In areas on the edge of water, such as lakes, settlement patterns tend to be irregular, clustered, and grow naturally.

According to Figure 1, the Pangururan area is located near the edge of Lake Toba. The development of settlements on the water's edge began with the existence of an ethnic group who settled on the water's edge and developed naturally from generation to generation. So it is often found that people who live on the edge of the water are homogeneous, closed and develop traditions and values or norms that apply to these ethnic groups [9]. 


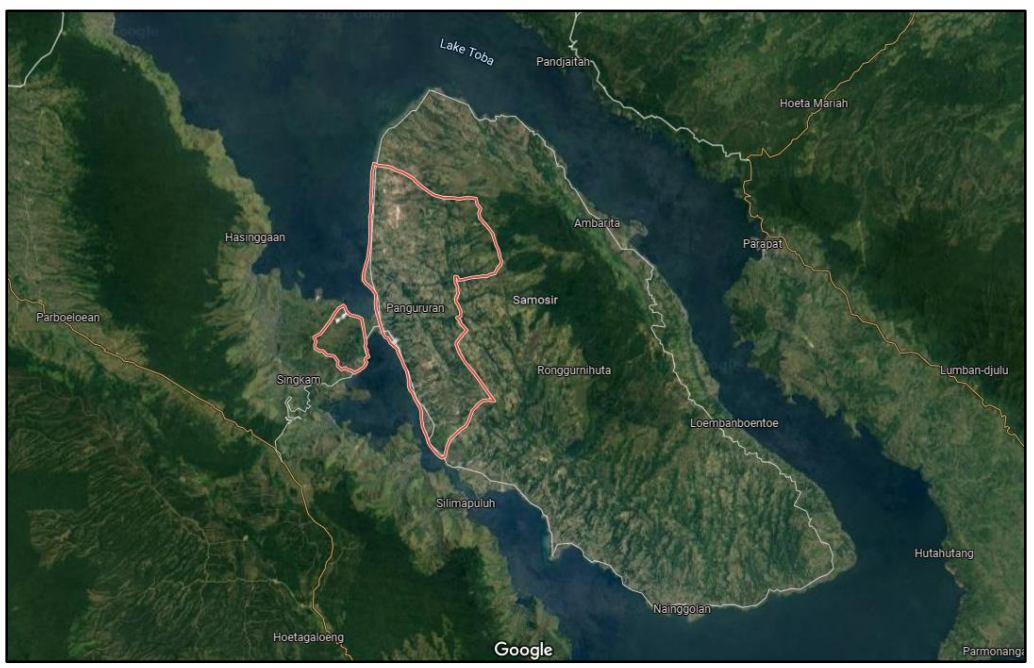

Figure 1 Location of Pangururan

The most common vernacular building located in Pangururan Distrik is Batak Toba traditional house as can be seen in figure 2. Generally, the development of settlements around Lake Toba is built by taking into account several aspects that may be the same as other traditional settlements in Indonesia. Traditional settlements were initially built by taking into account environmental, geographical, and cultural aspects [10]. The aspects that affect the settlement structure in Pangururan village are the influence of sunlight which causes the orientation of the buildings in Pangururan village to face west and east, the influence of wind direction which causes the orientation of the building to face the direction of air circulation. and create a large yard to respond to aspects of air circulation, the influence of topography on the growth of settlements, the influence of natural features such as the culture of the traditional beliefs of the Toba Batak people to orient the building towards Pusuk Buhit, the influence of social activities, the influence of community culture due to the marriage of two people which has the Toba Batak tribe and then creates the emergence of new villages [11].

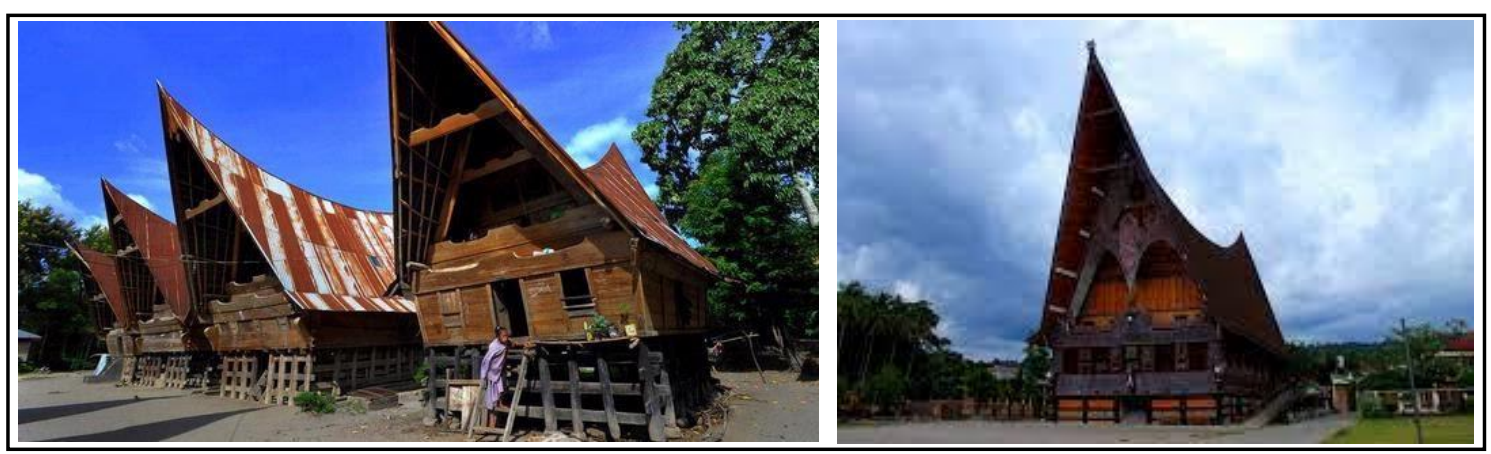

Figure 2 Vernacular Building in Pangururan

According to figure 3, Toba people are the most numerous of the Batak people of North Sumatra [12]. The concept of the Toba Batak people about human life is that their lives are always related and governed by customary values. Cultural values as identity in the Batak ethnic group are clan, language-script, and customs. Marga is the name of an association of a group of 
people who are descended from a grandfather according to the father's lineage, who generally own land together in the ancestral land. Language and script are also the identity of the Batak ethnic group. In the cultural system of the Toba Batak people, there are complex rules governing how humans behave in everyday life, both written and oral rules that come from their ancestors. These rules consist of a belief system (divinity), kinship system, social system, livelihood system, marriage system, customs, etc [13].

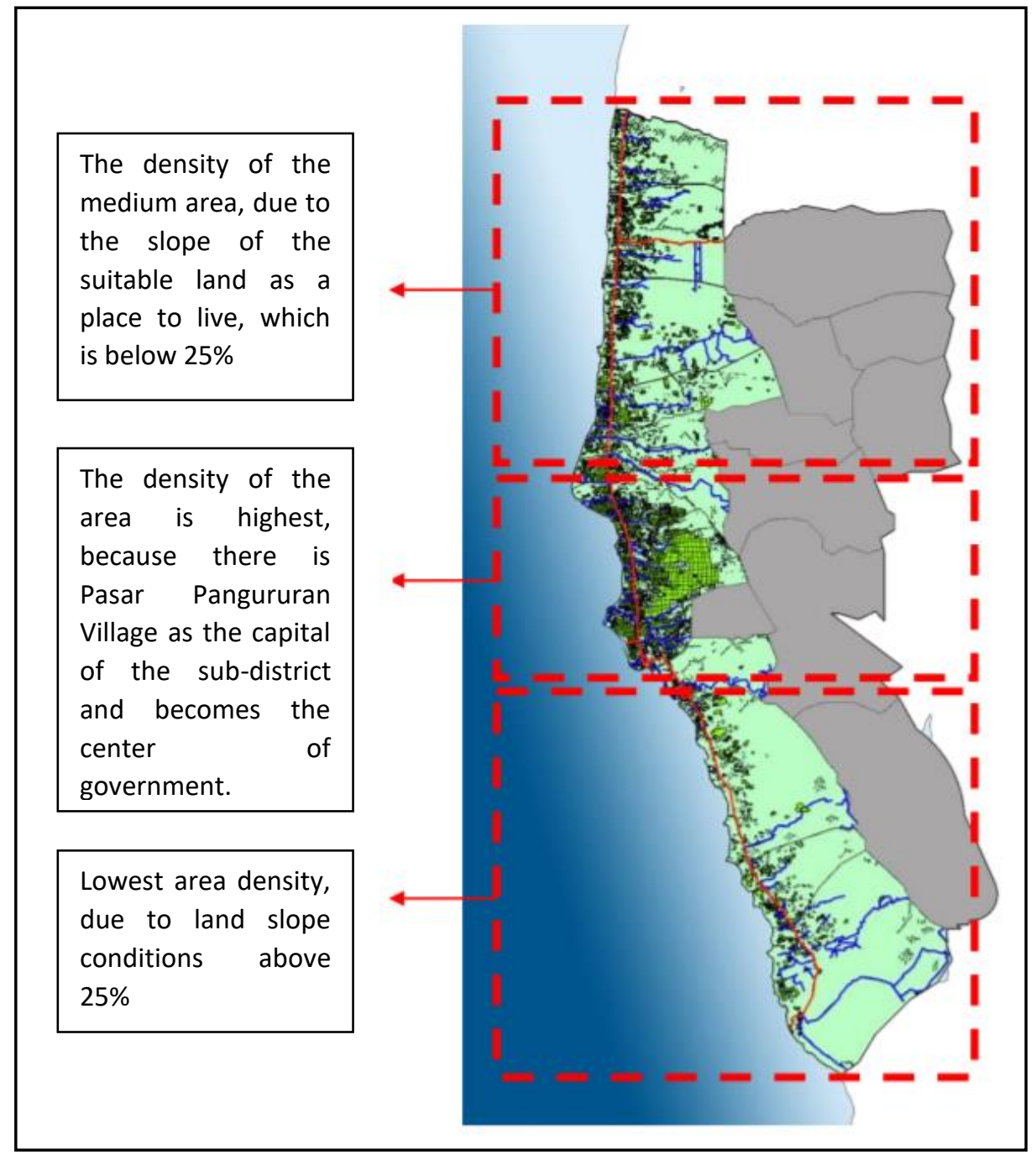

Figure 3 Ilustration of Density in Pangururan

Batak Toba vernacular architecture is one of the Architectural Culture found in North Sumatra which has developments that have been change and growth in terms of culture from time to time quite a long period of time. Diversity of religions, ethnicities, cultures and languages found in the area it is one of the usual used as a reference for development that culture. Art in Pangururan District is also no less in contributing to the growth of settlements. Batak people in general always give certain patterns that contain their own meaning from their ancestors. These patterns are often found in traditional houses in rural areas and known as Gorga [14]. 
The growth of settlements areas in Pangururan in Samosir Regency has a relationship with the way of life in the daily activities of the people. In the construction of settlements, the community will also adjust to the physical form of nature and culture. The topography of this area is quite flat on the edge of the lake, with a height of $0-20 \mathrm{~m}( \pm 10 \%)$. While on the east side of the land, the slope area reaches $2,150 \mathrm{~m}( \pm 25 \%)$. This flat topography is the most accessible area for the community. This ease of access causes this area to have many settlements and agricultural land managed by local communities [15].

The spatial characteristics of culture in Pangururan village are still found, especially in settlements on hills and on the edge of the lake which are influenced by variations in community social activities, most of which work as farmers and fishermen. The spatial structure in Pangururan village is the result of environmental adaptation from the efforts of the Toba Batak people in solving geographical and cultural problems.

\section{REFERENCES}

[1] Lestari, R. A., Kajian Aspek Ekologi dalam Membentuk Perkampungan di Kawasan Pangururan. Medan: TALENTA Publisher, 2019.

[2] Hillier \& Hanson, "The social logic of space", Cambridge: Cambridge University Press, 1984.

[3] Han, P., "The Spatial Structure of the Traditional Settlement, a Study of Clan Village in Korean Rural Area”, Journal of Architectural Institute of Korea, Vol. 9, No. 7, 1991.

[4] Rapoport, A., "Dwelling Settlement and Tradition", Prentice Hall Inc. London, 1989.

[5] Keesing, R. M., "Theories of culture", Annual review of anthropology. 3(1), 1974. p 73-97.

[6] Krisna, R., Antariksa. Studi Pelestarian Kawasan Wisata Budaya Di Dusun Sade Kabupaten Lombok Tengah. Jurnal Plannit. 3(2), 2005. p124-133.

[7] Hawkins, P., "Creating a Coaching Culture: Developing a Coaching Strategy for Your Organization," Berkshire: McGraw-Hill Education, 2012.

[8] Abdullah, "Upaya Meningkatkan Income Penduduk Kawasan Penyangga Kota Melalui Penataan Prasarana Permukiman", Laporan penelitian. Lemlit Universitas Tadulako, Palu, 2000.

[9] Suprijanto, I., Rumah Tradisional Osing Konsep Ruang dan Bentuk. Jurnal Dimensi, Vol. 30. No.1. 2002.

[10] Tiwi, P., Penelitian Dan Pemanfaatan Sumber Daya Budaya. Banten: IAAI Komisariat Daerah Jawa Barat, 2008

[11] Marpaung, B. O. Y. dan Robin, Ekologi dan Budaya Pembentuk Permukiman Tepi Air di Kecamatan Pangururan. Medan: Universitas Sumatera Utara, 2019.

[12] Triska, D., Kajian Regulasi Pembangunan Permukiman Area Tepi Air Di Pangururan Kabupaten Samosir. Medan: Universitas Sumatera Utara, 2019.

[13] Setiawan, T., Bentuk Adaptasi Lingkungan pada Permukiman Tradisional di Danau Toba. Medan: Balai Arkeologi Medan, 2010.

[14] Rambe, Y. S., "Architectural Analysis of the Toba Batak Traditional House in Toba Samosir Regency", Medan: Universitas Medan Area, 2019.

[15] Marpaung, Beny \& Triska, Daniel. 2020. Study of regulation development of settlements in the edge of water in Pangururan Samosir District. IOP Conference Series: Earth and Environmental Science. 452. 012133. 10.1088/1755-1315/452/1/012133. 